\title{
EVALUATION OF BIOGAS COLLECTION FROM REED CANARY GRASS, DEPENDING ON NITROGEN FERTILISATION LEVELS
}

\author{
Anna Kacprzak $^{* 1}$, Mariusz Matyka ${ }^{2}$, Liliana Krzystek ${ }^{1}$, Stanisław Ledakowicz $^{1}$ \\ ${ }^{1}$ Technical University of Lodz, Faculty of Process and Environmental Engineering, Department of \\ Bioprocess Engineering, Wolczanska 213, 90-924 Lodz, Poland \\ ${ }^{2}$ Institute of Soil Science and Plant Cultivation - State Research Institute in Puławy, Department of \\ Systems and Economics of Crop Production, Czartoryskich 8 St, 24-100 Puławy, Poland
}

\begin{abstract}
The world in $21^{\text {st }}$ century is facing the problem of growing energy consumption while the supply of fossil fuels is being reduced. This resulted in the development of research into the use of renewable energy sources and development of new technologies for energy production. In Polish conditions the development of agricultural biogas plants finds its legitimacy in the document developed by the Ministry titled "Trends in agricultural biogas plants in Poland in 2010-2020". The purpose of this study was to investigate the influence of the weather conditions and the degree of nitrogen fertilisation on yield of reed canary grass (Phalaris Arundinacea L.) and to determine their susceptibility to anaerobic digestion, and usefulness of the production of biogas. Carried out experiments showed that increasing nitrogen fertilisation (from 40 to $120 \mathrm{~kg} \mathrm{~N} / \mathrm{ha}$ ) linearly increased canary grass green biomass yield from 32 to $46.3 \mathrm{t} / \mathrm{ha}$. However, the highest biogas yield $126 \mathrm{~m}^{3} / \mathrm{ha}$ was obtained when $80 \mathrm{~kg} \mathrm{~N} / \mathrm{ha}$ was applied.
\end{abstract}

Keywords: biogas, reed canary grass, fertilisation

\section{INTRODUCTION}

Climate change is the most pressing contemporary ecological threat, and the global aim of preventing the rise of $\mathrm{CO}_{2}$ levels in the atmosphere has increased the need for renewable energy sources. Potentially sustainable bioenergy may be obtained from various energy crops, many of which are perennial grasses (Vepsäläinen, 2010). Among those crops reed canary grass (Phalaris Arundinacea L.) was one of most promising energy grasses (Burvall, 1997). This crop is tolerant to local climatic conditions with high biomass production potential. The practical cultivation knowledge of this species comes from our Scandinavian neighbours who have investigated this crop for bioenergy options already for a long period (Heinsoo et al., 2011). Grass biomass is also a common feedstock in many biogas plants across Europe (Gunnarson et al., 2008). In Polish conditions, the development of agricultural biogas plants finds its legitimacy in the document prepared by the Ministry of Economy: "Trends in agricultural biogas plants in Poland in 2010-2020". It envisages the establishment up to 2020 an average of one agricultural biogas plants in each municipality using biomass from agricultural sources, assuming ownership by the municipality the right conditions to start this project (Kopiński et al., 2011).

Nitrogen $(\mathrm{N})$ availability has been reported as the most frequently limiting factor for growth of native grasses, suggesting that $\mathrm{N}$ fertilisation can be an important management practice for canary grass 
biomass production and feedstock quality (Wang et al., 2010; Sanderson et al., 2008). Yet, there is still a lack of information regarding the impact of $\mathrm{N}$ fertilisation on biomass yield of canary grass, especially in Poland.

The objectives of the study were to evaluate the effects of $\mathrm{N}$ fertilisation on canary grass biomass yield as well as on biogas production and methane content.

\section{MATERIALS AND METHODS}

The plant material used for the preparation of silage was obtained from a field experiment located in the medium soil in Osiny, Experimental Station IUNG-PIB $\left(51^{\circ} 28^{\prime} \mathrm{N}, 21^{\circ} 39^{\prime} \mathrm{E}\right)$. The experiments were conducted in a randomised complete block design in "split-plot" system, with 4 replications in 20102011, which differed in the course of weather conditions (Tab 1).

Table 1. Meteorological conditions during the conducted experiments

\begin{tabular}{|c|c|c|c|c|c|c|c|c|}
\hline \multirow{2}{*}{ Year } & \multicolumn{1}{|c|}{ Month } \\
\cline { 2 - 8 } & III & IV & V & VI & VII & VIII & IX & III-IX \\
\hline \multicolumn{10}{|c|}{ Aainfall in $\mathrm{mm}$} \\
\hline 2010 & 29 & 34 & 93 & 18 & 107 & 151 & 75 & 506 \\
\hline 2011 & 12 & 14 & 38 & 101 & 133 & 68 & 37 & 402 \\
\hline \multicolumn{1}{|c|}{ Average temperature in ${ }^{\circ} \mathrm{C}$} \\
\hline 2010 & 2.4 & 7.8 & 11.5 & 16.7 & 21.6 & 18.4 & 12.2 & \\
\hline 2011 & 2.2 & 10.5 & 13.5 & 17.7 & 17.5 & 17.7 & 14.3 & - \\
\hline
\end{tabular}

Source: Our own study

The experience factor was the level of nitrogen fertilisation $\left(\mathrm{kg}^{\circ} \mathrm{ha}^{-1}\right)$ : N1 -40 ; N2 - 80; N3 - 120. The content of available phosphorus in the soil was (mg per $100 \mathrm{~g}$ of soil): 16.5; potassium 17.0; magnesium 12.2; the humus content of $1.8 \%$ and $\mathrm{pH} 5.8$ Mineral fertilisers were used $60 \mathrm{~kg} \cdot \mathrm{ha}^{-1}$ phosphorus i $80 \mathrm{~kg} \cdot \mathrm{ha}^{-1}$ potassium. Reed canary grass seeds, Swedish varieties Bamse were sown 2404-2010 in the amount $25 \mathrm{~kg} \cdot \mathrm{ha}^{-1}$ in row with spacing of $12 \mathrm{~cm}$ to a depth of $1.5-2.0 \mathrm{~cm}$. Yields were collected in two swaths: second decade of June and the third decade of October.

Significant differences as to the influence of the studied factors on the observed features were evaluated by the analysis of variance, setting confidence half-intervals at a significance level $\alpha=$ 0.05 . Statistical analyses were carried out using the software Statistica 10.

Based on the results of preliminary studies for silage dry matter, organic matter and dry matter content of elements $\mathrm{C}, \mathrm{N}, \mathrm{H}, \mathrm{S}$ the initial load of the bioreactor was selected. A weighed portion of the silage with the anaerobic sludge was placed in a sealed fermentation vessel with a working volume of $1 \mathrm{dm}^{3}$ in order to perform Biochemical Methane Potential (BMP) analysis. Then bioreactors were placed in a shaker with thermostat sustaining temperature of $37^{\circ} \mathrm{C}$. The contents of the bottles were flushed with $\mathrm{N}_{2} / \mathrm{CO}_{2}$-gas for 5 minutes and the bottles were then sealed with rubber stoppers. Daily methane production from each digester was measured using a water displacement. The biogas composition was analysed periodically using a SRI $8610 \mathrm{C}$ gas chromatograph (SRI Instruments, USA) equipped with TCD detector and two chromatographic columns: a column packed with Silica Gel No. 8 and 5A molecular sieve mesh $80 / 100$. The reactors ran until no further methane production could be detected. 
At the beginning and the end of batch fermentation, the contents of the bioreactors were analyzed for $\mathrm{pH}$, dry matter, organic solids, according to PN-75 C-04616/01, dichromates COD method using reagents and a spectrophotometer DR/5000 Hach-Lange's (method No. 435), elemental content (C, H, N, S) of inoculum and individual experimental feeds (Elemental Analyzer NA 2500, CE Instruments). Anaerobic sludge obtained from a quasi-continuous bioreactor with a capacity of $100 \mathrm{dm}^{3}$ was used as the inoculum.

\section{RESULTS}

The yield of green mass of reed canary grass in 2010, depending on nitrogen fertilisation ranged from 22.3 to $30.6 \mathrm{t} \cdot \mathrm{ha}^{-1}$, and in 2011 from 41.7 to $62.0 \mathrm{t} \cdot \mathrm{ha}^{-1}$ (Tab. 2). The obtained results indicate major variations in crop yields in the two respective years of the research. This is mainly due to the fact that reed canary grass as a perennial crop in the first year of vegetation (2010) failed to reach full yield potential. This is also reflected in the crop reaction on the level of nitrogen fertilisation. A statistical analysis showed that in 2010 yield of green mass differed significantly only between the lowest (40 $\left.\mathrm{kgN} \cdot \mathrm{ha}^{-1}\right)$ and highest $\left(120 \mathrm{kgN} \cdot \mathrm{ha}^{-1}\right)$ dose of nitrogen. However, for dry mass yield in 2010 , the differences were not so significant depending on the applied dose of nitrogen fertilisation.

Table 2. Yielding of reed canary grass in 2010-2011

\begin{tabular}{|c|c|c|c|c|c|}
\hline \multirow{3}{*}{ Year } & $\begin{array}{c}\text { Level of nitrogen } \\
\text { fertilization }\left[\mathrm{t} \cdot \mathrm{ha}^{-1}\right]\end{array}$ & $\begin{array}{c}\text { Yield of green } \\
\text { mass }\left[\mathrm{t} \cdot \mathrm{ha}^{-1}\right]\end{array}$ & $\begin{array}{c}\text { Yield of dry } \\
\text { mass }\left[\mathrm{t} \cdot \mathrm{ha}^{-1}\right]\end{array}$ & $\begin{array}{c}\text { Share of dry } \\
\text { mass }[\%]\end{array}$ & $\begin{array}{c}\text { Yield of silage* } \\
{\left[\mathrm{t} \cdot \mathrm{ha}^{-1}\right]}\end{array}$ \\
\hline \multirow{3}{*}{2010} & 40 & 22.3 & 5.7 & 25.4 & 16.7 \\
\cline { 2 - 6 } & 80 & 27.5 & 6.5 & 23.6 & 20.7 \\
\cline { 2 - 6 } & 120 & 30.6 & 7.1 & 23.1 & 22.9 \\
\hline \multirow{3}{*}{2011} & 40 & 41.7 & 11.9 & 28.4 & 31.3 \\
\cline { 2 - 6 } & 80 & 47.7 & 13.8 & 28.9 & 35.8 \\
\hline \multirow{3}{*}{ Average } & 120 & 62.0 & 17.4 & 28.1 & 46.5 \\
\cline { 2 - 6 } & 40 & 32.0 & 8.8 & 27.4 & 24.0 \\
\cline { 2 - 6 } & 120 & 37.6 & 10.2 & 27.0 & 28.2 \\
\hline
\end{tabular}

*silage yield specified on the basis of norms (green mass yield $\cdot 0.75$ )

Source: Our own study

The results obtained in 2011 are different, when the reed canary grass plants reach full yield potential. A statistical analysis showed that the yields for both green and dry mass of reed canary grass in 2011 differed significantly depending on the level of nitrogen fertilisation.

The share of dry matter in yield of reed canary grass, the average for years of research, was not dependent on the dose of nitrogen and was about $27 \%$.

For the biogas experiments silages of canary grass of three different levels of fertilisation were taken. Silages were analysed in order to check their productivity of biogas. The results of performed Biochemical Methane Potential (BMP) analysis are presented in Table 3. 
Table 3. Biogas productivity

\begin{tabular}{|c|c|c|c|c|c|}
\hline & biogas $\left[\mathrm{dm}^{3}\right]$ & $\begin{array}{c}\text { biogas } \\
{\left[\mathrm{m}^{3} \text { from }\right.} \\
1 \mathrm{tg} . \mathrm{m} *]\end{array}$ & $\begin{array}{c}\text { Biogas } \\
{\left[\mathrm{m}^{3} / \mathrm{ha} / \text { year }\right]}\end{array}$ & $\begin{array}{c}\text { crop yield } \\
\text { g.m. [dt/ha] }\end{array}$ & methane [\%] \\
\hline $\begin{array}{c}\text { Canary grass } \\
40 \mathrm{~N}\end{array}$ & 2.46 & 123 & 3936 & 32 & 53 \\
\hline $\begin{array}{c}\text { Canary grass } \\
80 \mathrm{~N}\end{array}$ & 2.52 & 126 & 4738 & 37.6 & 54 \\
\hline $\begin{array}{c}\text { Canary grass } \\
120 \mathrm{~N}\end{array}$ & 0.91 & 45.5 & 2107 & 46.3 & 49 \\
\hline
\end{tabular}

*g.m.- green mass

Improving biomass yield of dedicated energy crops on a limited area of land is cited as one of the possible strategies for achieving an effective and sustainable use of bioenergy (Erisman et al., 2010). For bioenergy cropping systems, $\mathrm{N}$ fertiliser use is a key agricultural management practice for improving productivity and profitability (Ceotto et al., 2011; Erisman et al., 2010) . In the present study, increasing nitrogen fertilisation linearly increased canary grass biomass yield. The difference between the first and second levels of fertilisation was not significant. The highest difference in the green mass yield was observed comparing application of 40 and $120 \mathrm{~kg} \mathrm{~N} / \mathrm{ha}$. This, however, was not reflected in the production of biogas. The best yield of biogas $126 \mathrm{~m}^{3} / \mathrm{t} \mathrm{g.m}$. was obtained from canary grass with applied $80 \mathrm{~kg} \mathrm{~N} / \mathrm{ha}$ and the lowest one $45.5 \mathrm{~m}^{3} / \mathrm{t} \mathrm{g.m.} \mathrm{from} \mathrm{the} \mathrm{highest} \mathrm{level} \mathrm{of} \mathrm{fertilisation}$ $(120 \mathrm{~kg} \mathrm{~N} / \mathrm{ha})$. The cumulative biogas production from BMP analysis is presented in Figure 1.

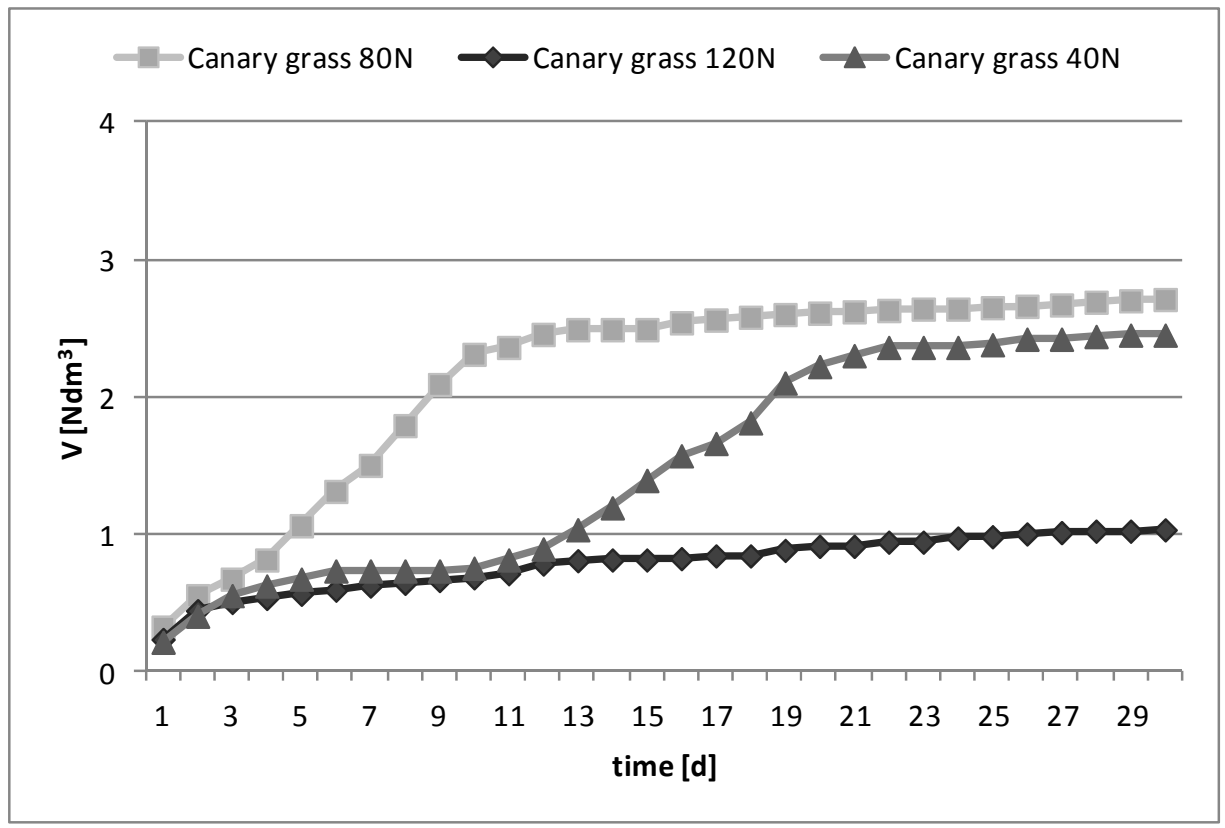

Fig. 1. Cumulative biogas production from Canary grass corresponding to three different levels of fertilisation

The methane content was the lowest (49\%) when the highest amount of $\mathrm{N}(120 \mathrm{~kg} / \mathrm{ha})$ was applied, while it did not differ significantly $53-54 \%$ with the dose of nitrogen of 40 and $80 \mathrm{~kg} /$ ha respectively.

\section{CONCLUSIONS}

The field experiments from 2010 showed that increase of green mass yield of reed canary grass depended on the fertilisation level. The highest difference was noticeable when comparing the lowest $\left(40 \mathrm{kgN} \cdot \mathrm{ha}^{-1}\right)$ and highest $\left(120 \mathrm{kgN} \cdot \mathrm{ha}^{-1}\right)$ doses of nitrogen. However, for dry matter yield there were 
no statistically significant differences depending on the applied dose of nitrogen fertilisation. Nevertheless, in 2011 when the reed canary grass plants reached their full yield potential, the yields of both green and dry mass of reed canary grass differed significantly depending on the level of nitrogen fertilisation.

This, however, was not reflected in the production of biogas. The best yield of biogas $126 \mathrm{~m}^{3} / \mathrm{t} \mathrm{g.m}$. was obtained from canary grass with the applied $80 \mathrm{~kg} \mathrm{~N} / \mathrm{ha}$ and the lowest one $45.5 \mathrm{~m}^{3} / \mathrm{t} \mathrm{g.m}$. from the highest level of fertilisation (120 kg N/ha).

Allison et al. (2012) stated that the use of nitrogen fertilisers can cause an increase in lignin content. In the case of reed canary grass, this increase can affect the growth of calorific value and improve crop yields. On the other hand, it may have a negative effect on the susceptibility of grass to the conversion process such as anaerobic digestion. This can be the reason for low biogas production from the silage with the highest dose of nitrogen $(120 \mathrm{~kg} / \mathrm{ha})$. Further studies are planned to investigate the influence of the dose of nitrogen fertilisation on the yield of biogas production from different energy crops.

The work is funded by the European Union under the Operational Programme Innovative Economy 2007-2013: POIG.01.03.01-00-132/08 (European Regional Development Fund).

\section{REFERENCES}

Allison G., Morris C., Lister S., Barraclough T., Yates N., Shield I., Donnison I., 2012. Effect of nitrogen fertilizer application on cell wall composition in switchgrass and reed canary grass. Biomass Bioenergy, 40, 1926. DOI: 10.1016/j.biombioe.2012.01.034.

Burvall J., 1997. Influence of harvest time and soil type on fuel quality in red canary grass (Phalaris Arundinacea L.). Biomass Bioenergy, 12, 149-154. DOI: 10.1016/S0961-9534(96)00064-5.

Ceotto E., Di Candilo M., 2011. Sustainable bioenergy production, land and nitrogen use, In: Lichtfouse E. (Ed.), Biodiversity, biofuels, agroforestry and conservation agriculture. Sustainable agriculture reviews, 5, 101-22. DOI: $10.1007 / 978-90-481-9513-8 \_3$.

Erisman J.W., van Grinsven H., Leip A., Mosier A., Bleeker A., 2010. Nitrogen and biofuels; an overview of the current state of knowledge. Nutr. Cycl. Agroecosyst., 86, 211-23. DOI: 10.1007/s10705-009-9285-4.

Gunnarsson C., Vagström L., Hansson P.A., 2008. Logistics for forage harvest to biogas production - Timeliness, capacities and costs in a Swedish case study. Biomass Bioenergy, 32, 1263-1273. DOI: 10.1016/j.biombioe.2008.03.004.

Heinsoo K., Hein K., Melts I., Holm B., Ivask M., 2011. Reed canary grass yield and fuel quality in Estonian farmers' fields. Biomass Bioenergy, 35, 617-625. DOI: 10.1016/j.biombioe.2010.10.022.

Kopiński J., Matyka M., Madej A., 2011. Influence of environmental conditions on the profitability of maize cultivation for biogas. Rocz. Nauk. SERiA, 13, , 35-38.

Sanderson M.A., Adler P.R., 2008. Perennial forages as second generation bioenergy crops. Int. J. Mol. Sci., 9, 768-78. DOI: 10.3390/ijms9050768.

Vepsäläinen V., 2010. Energy crop cultivations of reed canary grass - An inferior breeding habitat for the skylark, a characteristic farmland bird species. Biomass Bioenergy, 34, 993-998. DOI: 10.1016/j.biombioe.2010.02.007.

Wang D., Lebauer D.S., Dietze M.C., 2010. A quantitative review comparing the yield of switchgrass in monocultures and mixtures in relation to climate and management factors. Glob. Change Biol. Bioenerg., 2, 1625. DOI: $10.1111 / \mathrm{j} .1757-1707.2010 .01035 . x$. 